\title{
Correction to: Laboratory Study on the use of Reclaimed Asphalt Pavement and Copper Slag in Warm Mix Asphalt Pavements using Waste Engine Oil as a Rejuvenator
}

\author{
Ishfaq Mohi Ud Din ${ }^{1}\left[\right.$ Mohammad Shafi Mir $^{1}$
}

Published online: 17 September 2021

(c) Chinese Society of Pavement Engineering 2021

\author{
Correction to: \\ International Journal of Pavement Research and \\ Technology \\ https://doi.org/10.1007/s42947-021-00036-y
}

During the correction process reference 2 has been cited two times. For this reason reference 49 has not been cited. Reference 49 should be read as follows:

49. Ud Din IM, Mir MS, Farooq MA (2020) Effect of freezethaw cycles on the properties of asphalt pavements in cold regions: a review. Transp Res Procedia 48:3634-3641. https://doi.org/10.1016/j.trpro.2020.08.087

The original article has been corrected.

The original article can be found online at https://doi.org/10.1007/ s42947-021-00036-y.

Ishfaq Mohi Ud Din

Ishfaq_34phd17@nitsri.net

1 Department of Civil Engineering, National Institute of Technology, Srinagar, J\&K 190006, India 